\title{
Palaeoecological significance of a palynofloral assemblage from Surma Group (Late Miocene) of Tamenglong area, Manipur, northeast India
}

\author{
Y Raghumani Singh ${ }^{1, *}$, KSH Atamajit Singh ${ }^{1}$ and Suman SarkaR ${ }^{2}$ \\ ${ }^{1}$ Department of Earth Sciences, Manipur University, Imphal 795 003, India. \\ ${ }^{2}$ Birbal Sahni Institute of Palaeosciences, 53 University Road, Lucknow 226 007, India. \\ ${ }^{*}$ Corresponding author.e-mail: yengmani@gmail.com
}

MS received 8 December 2017; revised 27 April 2018; accepted 8 May 2018; published online 1 February 2019

A Late Miocene palynofloral assemblage is recorded for the first time from the sediments of Surma Group exposed at Tamenglong area of Manipur. The assemblage mainly consists of fungal spores and Microthyriaceous ascostromata, algal remains, pteridophytic spores, gymnospermous and angiospermous pollen. The quantitative analysis indicates the dominance of bisaccate gymnosperm pollen (61\%) mainly represented by Podocarpidites and Pinuspollenites, followed by pteridophytic spores (23\%), algal and fungal remains (11\%) and angiosperm pollen grains (5\%). Abundance of Hammenisporis spp., fungal conidia and ascostromata along with Zygnemataceous zygospores in the assemblage indicates a warm, humid climate and freshwater depositional environment for the Surma sediments in the present area of investigation. Recorded palynofloral assemblage with the characteristic fungal Microthyriaceous ascostromata suggests a pro-delta to shoreface depositional environment. Representatives of families Parkeriaceae, Cyatheaceae, Gleicheniaceae, Hymenophyllaceae, Podocarpaceae, Araceae and Malvaceae indicate the prevalence of tropicalsubtropical climate. The Tamenglong palynofloral assemblage has been compared with some other assemblages known from the Mio-Pliocene sediments of India. The occurrences of abundant Pinuspollenites, Tsugaepollenites, Hibisceaepollenites and Parmathyrites in the present assemblage suggest a Late Miocene age.

Keywords. Palynofossils; Late Miocene; Surma Group; Manipur; palaeoenvironment.

\section{Introduction}

A large sedimentary basin comprising states of Manipur, Nagaland, Mizoram, Tripura, some parts of Assam and Arunachal Pradesh was formed due to the convergence of Indian and Myanmar plates in the northeastern part of India during the Cenozoic. This basin is mainly composed of Cretaceous and Tertiary sediments with minor proportions of igneous and metamorphic rocks belonging to the thick sequences of ophiolites, Disang, Barail, Surma and Tipam groups. Palynological investigations were carried out by several workers from different parts of this basin (Saxena et al. 1987; Mandaokar 2000, 2015; Kumar et al. 2001; Singh et al. 2011). However, very little palynological work has been done so far on the Neogene palynostratigraphy of Manipur. Only a few published records are available from the Palaeogene rocks of the Upper Disang Formation 
(Singh and Meera 2013; Singh et al. 2013, 2015, 2016a). During the course of biostratigraphical investigations of Manipur, the present authors have discovered and analyzed a well preserved Late Miocene palynofloral assemblage from the sediments of Surma Group exposed in the Tamenglong area. As far as the authors are aware, this is the first report of a Surma palynofloral assemblage from this region. The objectives of the present investigation are to record the palynofossils and utilize them for interpreting the depositional environment, palaeoclimate and geological age of the studied Surma sediments.

\section{Geological setting}

The sedimentary succession of Surma Group of rocks is named after its type locality in the Surma valley (Evans 1932). These rocks are exposed extensively in the northeastern part of India. In Manipur, these rocks occupy the western part of the state and are considered as a northwestern extension from Mizoram area where they are most well developed (figure 1). The molasse Miocene Surma Group of Surma-Barak Basin of Manipur has developed due to the upliftment of Himalayan and Indo-Myanmar range. The detritus of sandstone are mostly derived from collision suture fold belt. Sandstone of Surma Group is immature in texture as well as composition and deposited over eroded surface of the Barail Group (Kumar 1997; Devi and Mondal 2008). In the Tamenglong area, it also lies unconformably above the Oligocene Barail Group. Sedimentary rock succession of Surma Group is generally subdivided into two formations. The lower is the Bhuban Formation, whereas upper one is the Bokabil Formation. The lower Bhuban Formation is characterized by massive and thick bedded sandstones with siltstones and minor dark grey to khaki green thin bedded shales with locally exposed coal streaks, twigs and plant impressions. The Bokabil Formation unconformably overlies the Bhuban Formation and consists of mudstones, shales, silty shales and shales with massive, coarse grained sandstones (GSI 2011). However, the Surma Group is undifferentiated in Manipur region (table 1). The Tipam Sandstone Formation overlies the Surma Group and is characterized by massive, thick bedded sandstones with shales (Devi et al. 2010).

\section{Material and methods}

The material for the palynological investigation was collected from the Surma sediments exposed at Tamenglong-Barak unmetalled road (GPS: $\left.25^{\circ} 01^{\prime} 51.8^{\prime \prime} \mathrm{N}, 93^{\circ} 28^{\prime} 33.6^{\prime \prime} \mathrm{E}\right)$ in the Tamenglong area of Manipur (figure 2). All together 25 samples were collected from different horizons of the measured stratigraphic section. Out of these, six samples proved to be palynologically productive (figure 3). The productive samples are mostly claystones or fine grained siltstones. The palynofossils were recovered from the samples by using conventional technique of maceration that included treatment with $\mathrm{HCl}, \mathrm{HF}, \mathrm{HNO}_{3}$ and $\mathrm{KOH}$. The slides were prepared in polyvinyl alcohol and mounted in Canada balsam. A Nikon microscope unit (Eclipse E200) was used for the study as well as taking photomicrographs. The quantitative analysis is based on the frequency of the various palynotaxa in a count of 100 specimens per sample. The material and slides are deposited in the repository of the Department of Earth Sciences, Manipur University.

\section{Results and discussions}

\subsection{Palynological analysis}

The palynofloral assemblage of Surma Group from Tamenglong is composed of plant groups belonging to algae, fungi, pteridophytes, gymnosperms and angiosperms. In total, 23 genera and 35 species have been recorded (table 2). Of these, seven genera and ten species belong to fungi, six genera and nine species to pteridophytes, three genera and nine species to gymnosperms and, seven genera and seven species to angiosperms. Besides, commonly occurring Zygnemataceous zygospores and several reworked Gondwana palynofossils (Angulocolporites microreticulatus; Callialasporites sp.; Densipollenites sp.; Indotriradites sp.; Plicatipollenites indicus; Parvisaccites korbaensis; Parvisaccites sp.; Primuspollenites densus; Striatites communis and Undulatisporites sp.) have also been recorded. Some of the significant palynofossils are also illustrated in figure 4.

The known botanical affinities of the recorded palynotaxa and their present day distribution are given in table 2. Quantitative analysis of sporepollen belonging to different botanical groups in the present palynofloral assemblage is as follows: pteridophytic spores (23\%), gymnospermous pollen 


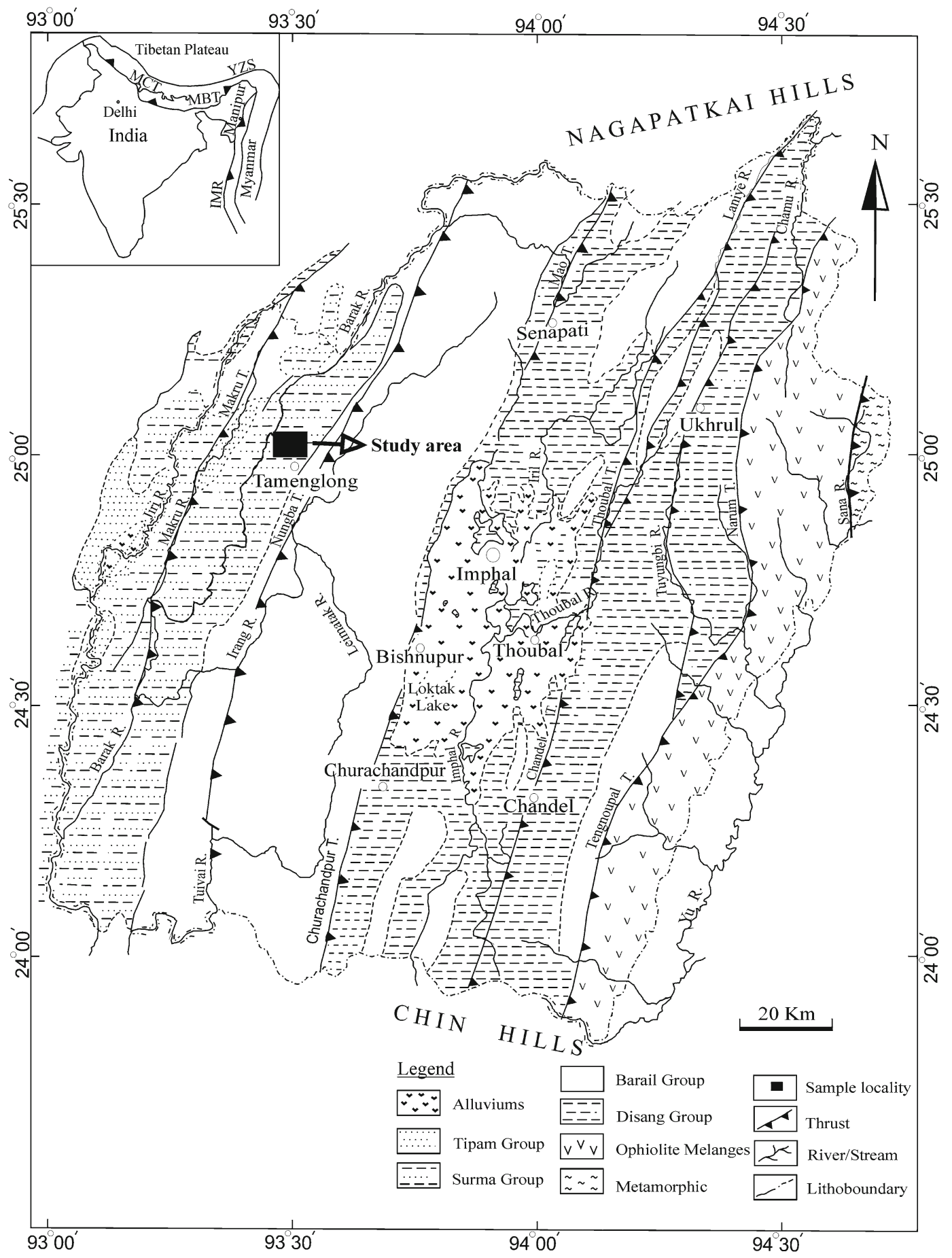

Figure 1. Geological map of Manipur and showing sample locality (after Singh et al. 2013).

(61\%), angiospermous pollen (5\%) and algal and fungal remains (11\%). Among the gymnospermous pollen, Podocarpidites (35\%) and Pinuspollenites $(42 \%)$ are the dominant elements. In case of the pteridophytic spores, Hammenisporis paucicostatus, H. susannae, H. multicostatus, Polypodiisporites sp. and Polypodiaceasporites sp. are the most common. Distribution pattern of the recorded palynotaxa is shown in figure 3 .

\subsection{Palynological comparison and age}

The presently studied palynofloral assemblage has been compared with other Neogene assemblages recorded from different parts of continental India to evaluate its dating potential. Sediments of the Surma Group studied from the outcrop sections in Mizoram have yielded benthic foraminifera like Rotalia umbonata, Orbulina bilobata and 
Table 1. Generalised lithostratigraphy of Tamenglong area (After GSI, 2011).

\begin{tabular}{|c|c|c|c|}
\hline Age & Group & Formation & Lithology \\
\hline Quaternary-Pleistocene & Alluvium & & Clay, silt, sand, gravel, pebble, boulder deposits \\
\hline Late Miocene & Tipam Group & & $\begin{array}{l}\text { Mottled clay, mottled sandy clay, sandy shale, } \\
\text { clayey shale and sandstone. Greenish to blue, } \\
\text { moderate to coarse ferruginous sandstone } \\
\text { with sandy shale, clay. Molasse type of } \\
\text { deposits }\end{array}$ \\
\hline Miocene & Surma Group & $\begin{array}{l}\text { Surma Group } \\
\text { (undifferentiated) }\end{array}$ & $\begin{array}{l}\text { Shale, siltstone alternation with minor } \\
\text { sandstone }\end{array}$ \\
\hline \multicolumn{4}{|l|}{ Unconformity } \\
\hline Oligocene & Barail Group & $\begin{array}{l}\text { Renji Formation } \\
\text { Jenam Formation } \\
\text { Laisong Formation }\end{array}$ & $\begin{array}{l}\text { Massive to thickly bedded sandstone. } \\
\text { Alternations of shale and sandstone with } \\
\text { carbonaceous matters. Intercalation of } \\
\text { bedded sandstone with shale. Flysch } \\
\text { sediments }\end{array}$ \\
\hline
\end{tabular}

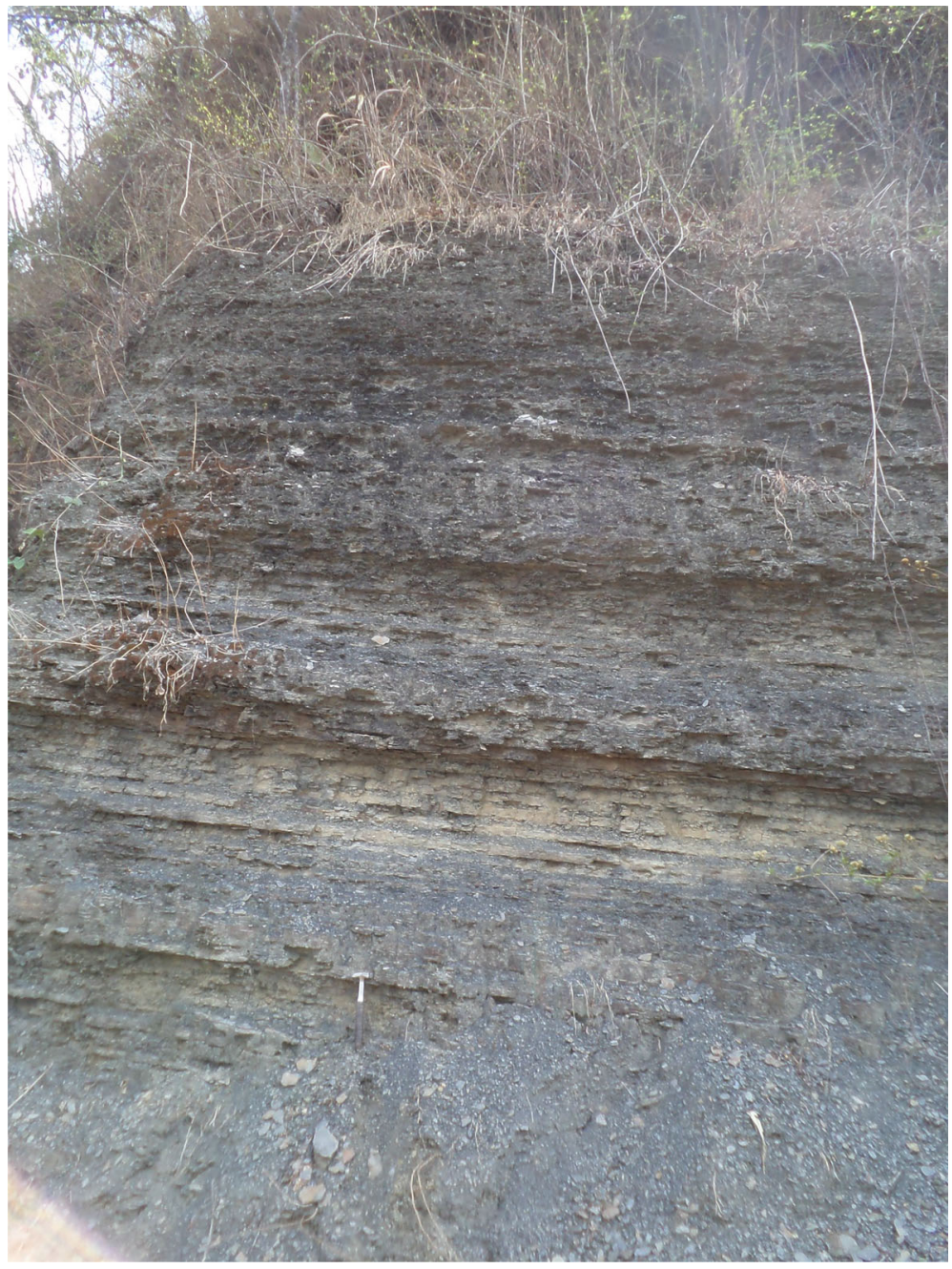

Figure 2. Field photograph showing the sampled outcrop of the study area.

Praeorbulina glomerosa that indicate a Middle Miocene age (Lokho and Raju 2007; Lokho et al. 2011). However, the section from Tamenglong area of Manipur examined in the current study is assignable to Late Miocene based on the overall assessment of palynofossils. Palynofloral assemblages from the Boldamgiri Formation (Early Miocene) of Garo Hills (Saxena and Rao 1996; 


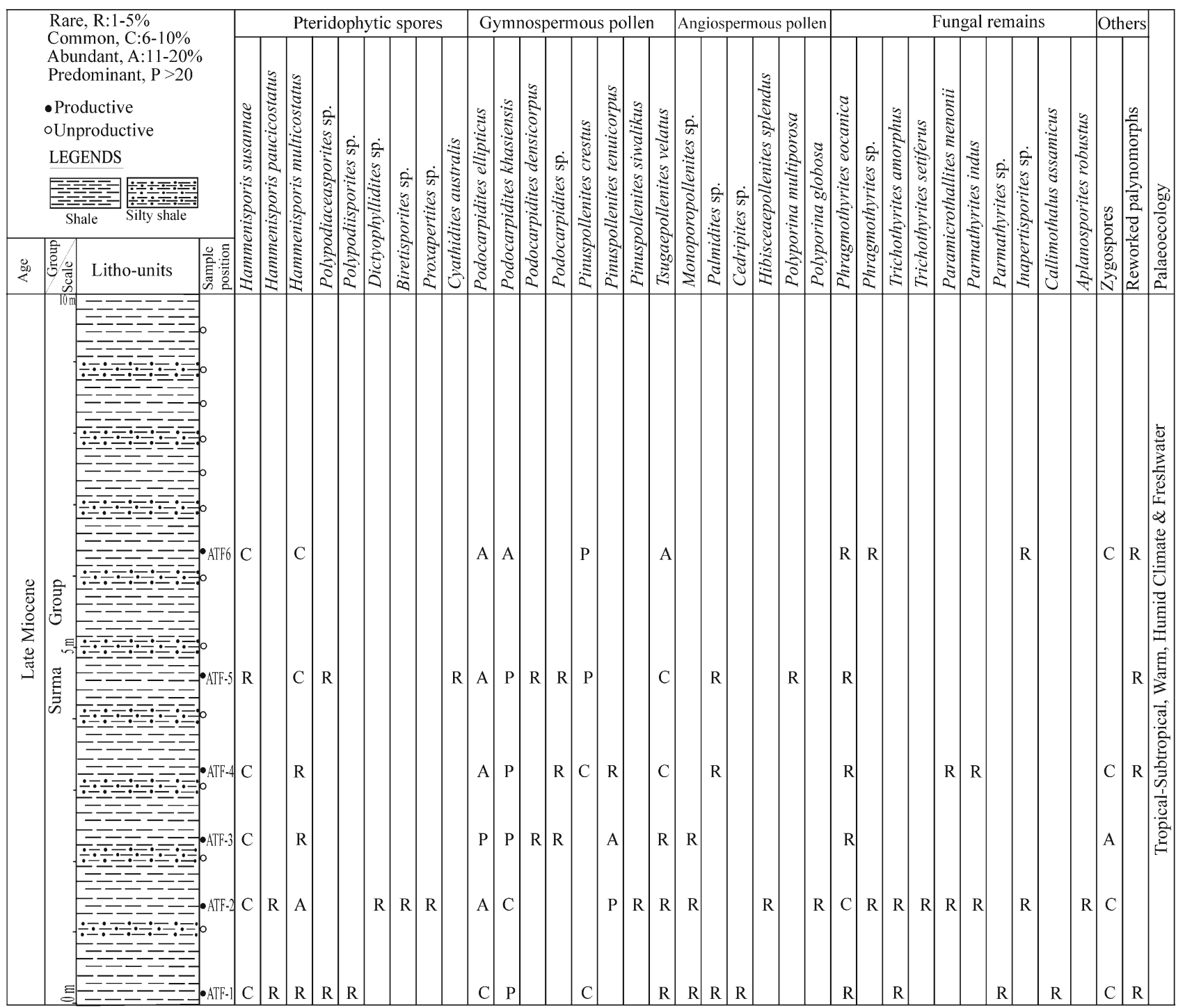

Figure 3. Distribution chart showing the significant palynotaxa in the Tamenglong Surma sediments and their palaeoecological affinities.

Nandi and Sharma 1984) are comparable to the present assemblage in the common occurrences of several palynotaxa, viz., Hammenisporis (Ceratopteris), Polypodiisporites, Polypodiaceasporites, Cyathidites, Pinuspollenites, Phragmothyrites, Inapertisporites and Biretisporites. Palynological assemblage recovered from the Miocene rocks of Maibong, Assam (Mandaokar 1990) is also closely comparable to the present assemblage in the presence of palynotaxa, viz., Hammenisporis (Ceratopteris), Polypodiaceasporites, Dictyophyllidites, Cyathidites, Podocarpidites, Pinuspollenites and Phragmothyrites. Miocene palynofloral assemblages recorded by Rao and Nair (1998), Mandaokar (2000, 2002), Rao (2004), Singh et al. (2011), Mandaokar and Mukherjee (2014) and Rao and
Verma (2014) show high degree of similarity with the assemblage reported in the present investigation due to several common paly-notaxa.

The present palynofloral assemblage closely resembles Late Miocene palynofloral assemblages recorded by Lukose (1968), Nandi (1975), Mathur (1984), Singh and Sarkar (1984), Sarkar (1990), and Sarkar et al. (1994) in the dominance of bisaccate pollen genera Pinuspollenites, Podocarpidites and pteridophytic spores of Hammenisporis (Ceratopteris), Polypodiaceaesporites and Polypodiisporites. The Surma (Miocene) palynofloral assemblage recorded from the Sonapur-Badarpur road section of the Jaintia Hills also shows the predominance of bisaccate pollen grains (Singh et al. 1986). Therefore, the presently recorded palynological 

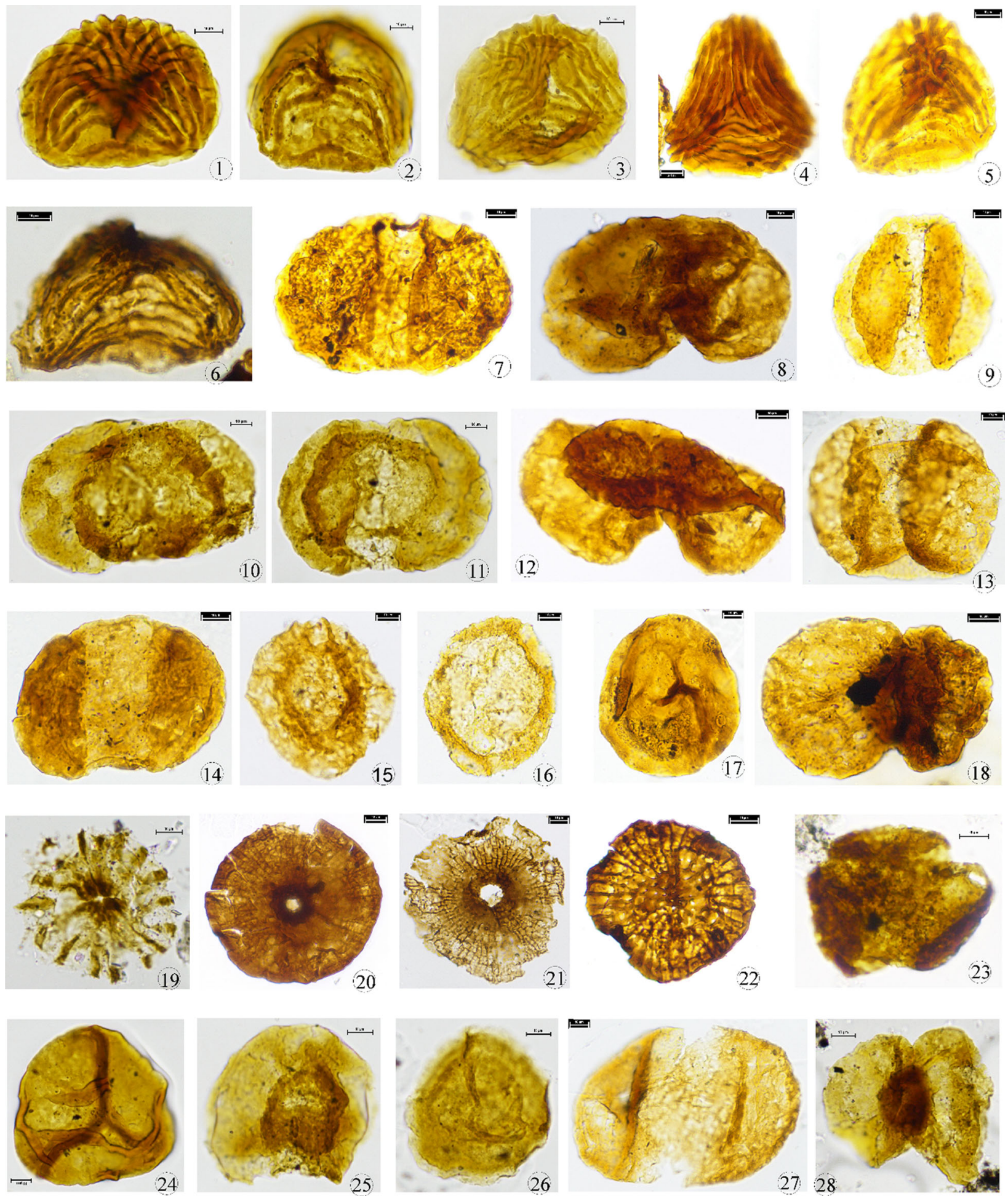

Figure 4. (1, 2, 5) Hammenisporis multicostatus; Slide nos. ATF-3(2)1; ATF-4(4)4; ATF-2(1)18A. (3, 4) Hammenisporis susannae; Slide nos. ATF-6(3)10; ATF-2(2)34B. (6) Hammenisporis paucicostatus; Slide no. ATF-1(1)16A. (7, 13, 27) Pinuspollenites tenuicorpus; Slide nos. ATF-2(1)34C; ATF-2(2)15A; ATF-2(1)23A. (8, 12) Pinuspollenites crestus; Slide nos. ATF-1(2)26A; ATF-1(3)7A. (9, 14) Podocarpidites ellipticus; Slide nos. ATF-2(3)33B; ATF-2(3)17A. (10, 11) Podocarpidites khasiensis; Slides nos. ATF-6(7)2A; ATF-4(1)16. (15, 16) Tsugaepollenites velatus; Slide nos. ATF-1(2)10A; ATF-2(1)40D. (17) Zygospore of Zygnemataceae; Slide no. ATF-2(2)29D. (18, 28) Primuspollenites densus; Slide no. ATF-2(2)2B; ATF6(1)18. (19) Incerti sedis type-1 (Plant scale); Slide no. ATF-6(2)7. (20) Paramicrothallites menonii; Slide no. ATF-2(1)2A. (21) Notothyrites setiferus; Slide no. ATF-2(1)1A. (22) Phragmothyrites eocaenica; Slide no. ATF-2(2)29A. (23) Angulocolporites microreticulatus; Slide no. ATF-6(6)8. (24) Undulatisporites sp.; Slide no. ATF-5(4)6. (25) Densipollenites sp.; Slide no. ATF-5(4)13. (26) Indotriradites sp.; Slide no. ATF-5(4)7. 


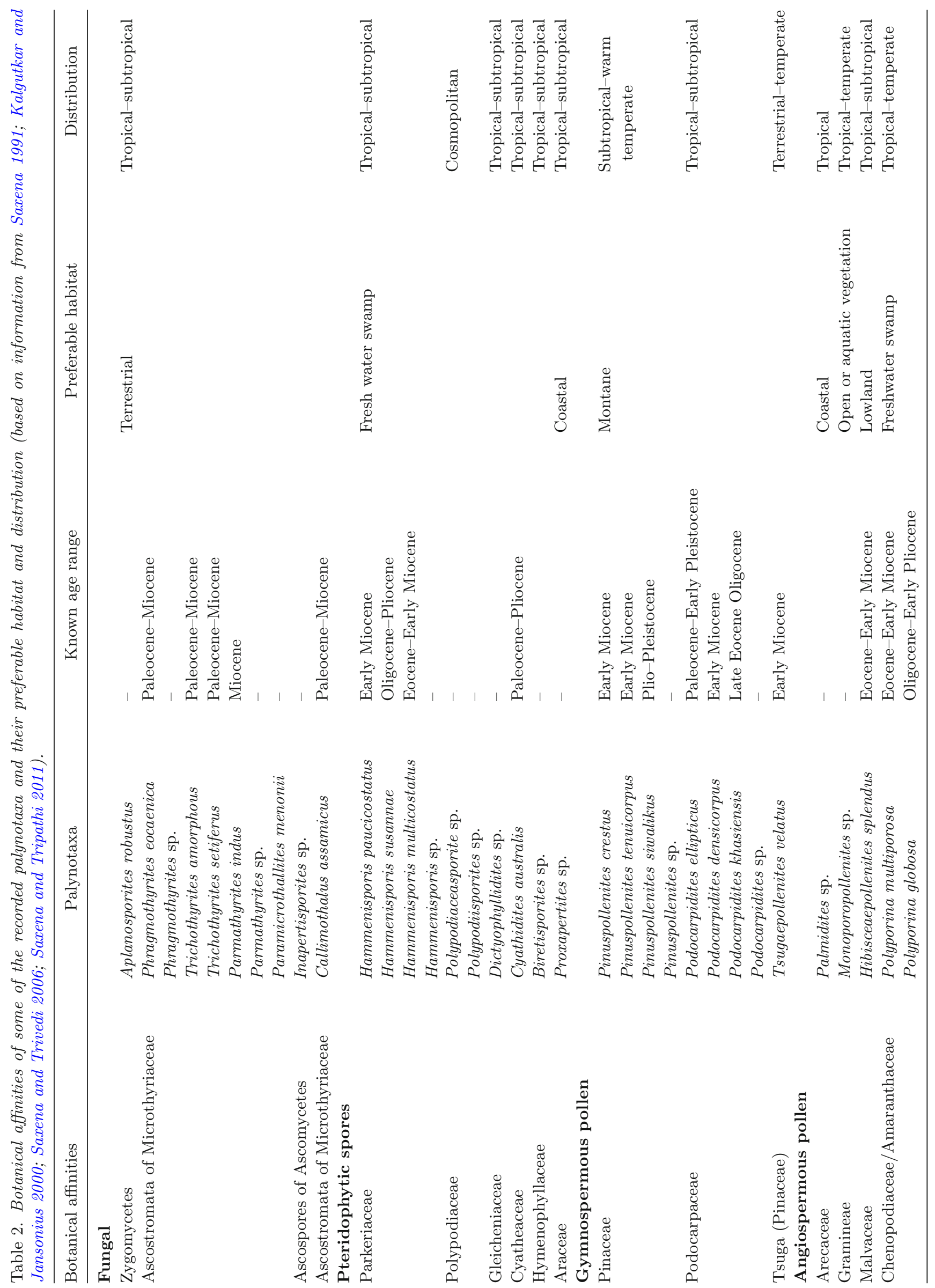


assemblage from the sediments of Surma Group of Tamenglong area is also assignable to the Late Miocene age.

\subsection{Palaeoclimate and environment of deposition}

The palynoflora comprises zygospores of Zygnemataceae, fungal spores and fruiting bodies, pteridophytic spores, angiospermous and gymnospermous pollen grains. Recorded pollen grains and spores are assignable to thirteen families (table 1). These are: Parkeriaceae, Polypodiaceae, Gleicheniaceae, Cyatheaceae, Hymenophyllaceae, Araceae, Pinaceae, Podocarpaceae, Tsuga (Pinaceae), Arecaceae, Gramineae, Malvaceae, Chenopodiaceae/Amaranthaceae. Of these the families Parkeriaceae, Gleicheniaceae, Hymenophyllaceae, Araceae, Cyatheaceae, Podocarpaceae and Malvaceae have their present day range restricted to the tropical-subtropical regions whereas family Polypodiaceae is cosmopolitan in distribution. The tropical and temperate elements are assignable to Chenopodiaceae, Gramineae and Pinaceae. The fungal remains are also well distributed throughout the succession. The overall vegetation pattern points toward a tropicalsubtropical, humid climate during the deposition of the Surma sediments in the present area of investigation.

Palynofossils belonging to five different ecological groups viz., terrestrial, montane, lowland, freshwater swamp and coastal elements have been recognized in the present palynoflora (table 2). An analysis of the ecological groups of the Tamenglong Surma sediments shows that the montane elements are predominant over the other ecological groups. The frequency of montane elements is less in the lower part and increases towards the top (figure 3 ). The higher percentage of montane taxa like Pinuspollenites and Podocarpidites in the section appear to be transported from the upland areas in the north. The freshwater elements such as Hammenisporis are well distributed throughout the assemblage and more abundant in the lower part of the studied section. The presence of Zygnemataceous zygospores in the horizon is indicative of stagnant shallow freshwater conditions during the sedimentation of Surma sediments. Lowland and coastal elements are distributed in low frequency in the lower horizons of the succession. The fungal remains are well distributed in all the horizons, which indicate warm and humid conditions with heavy rainfall. Based on the records of benthic foraminifera from the sediments of the Upper Bhuban Formation, Surma Group outcropping in Mizoram, an inner neritic to shallow-marine depositional environment is interpreted (Lokho and Raju 2007; Lokho et al. 2011). However, in the present investigation, no marine biotic fossils have been recorded that gives the definite impression that sediments of the Surma Group from Tamenglong area of Manipur were deposited under freshwater conditions. The characteristic fungal Microthyriaceous ascostromata recorded with the palynofossils also suggest a pro-delta to shoreface depositional environment.

During the present investigation, a large number of reworked palynofossils viz. Plicatipollenites indicus, Parvisaccites korbaensis, Parvisaccites sp., Primuspollenites densus, Striatites communis, Densipollenites sp., Callialasporites sp., Undulatisporites sp., Indotriradites andAngulocolporites microreticulatus, have been observed throughout the succession. Their occurrence in the Surma sediments suggests that the source of the transported sediments were most likely derived from the Gondwana rocks, which are extensively exposed at 10th Mile Chumukedima Gate, Nagaland (Singh et al. 2016b).

\section{Summary}

A Late Miocene palynofloral assemblage has been recorded for the first time from the Surma sediments of Tamenglong area, Manipur. The palynofloral assemblage mainly consists of algal and fungal remains, pteridophytic spores, gymnosperm and angiosperm pollen grains. In all 35 species belonging to 23 genera have been recorded. Qualitative and quantitative analyses reveal that the bisaccate gymnospermous pollen dominates over pteridophytic spores followed by algal-fungal remains and angiosperm pollen grains. Modern affinity of the recorded palynofossils points toward a topical-subtropical, warm and humid climate. Common to abundant Hammenisporis spp., zygospores of Zygnemataceae and fungal remains in the assemblage suggests a stagnant shallow freshwater depositional environment with heavy rainfall during the sedimentation of the Surma sediments. The presently studied Surma sediments have been assigned a Late Miocene age on the basis of the comparative study of the Tamenglong palynofloral assemblage with other known equivalent assemblages from various geological horizons of India. 


\section{Acknowledgements}

YRS is very much thankful to the Science and Engineering Research Board (SERB), New Delhi (Project No. EEQ/2016/000062) and Oil India Limited (Contract No. 6111262) for financial assistance in form of research project. The authors are also thankful to the anonymous reviewers and Dr. Samir Sarkar for their valuable suggestions that greatly improved the manuscript. The authors sincerely acknowledge Mr. Venus Guruaribam and Miss Reshma Naorem (Research Scholars) and Dr. S Ranjeeta Devi (Post Doctorate), Department of Earth Sciences, Manipur for their support during maceration and field work. One of us (SS) is also highly grateful to SERB, New Delhi for the financial support (SR/FTP/ES-143/2014).

\section{References}

Devi S R and Mondal M E A 2008 Provenance and tectonic setting of Barail (Oligocene) and Surma (Miocene) Group of Surma-Barak Basin, Manipur, India: Petrographic constraints; J. Geol. Soc. India 71 459-467.

Devi S R, Mondal M E A, Alam M M and Hota R N 2010 Petrography and textural characteristics of the Barail and the Surma sandstones from Barak Basin, western Manipur, in relation to depositional processes and orogeny; J. Indian Assoc. Sedimentiol. 28 77-86.

Evans P 1932 Tertiary succession in Assam; Trans. Min. Geol. Inst. India 27 155-260.

GSI 2011 Geology and mineral resources of Manipur, Mizoram, Nagaland and Tripura; Geol. Soc. India Misc. Publ. 30 8-29.

Kalgutkar R M and Jansonius J 2000 Synopsis of fungal spores, mycelia and fructifications; AASP Contrib. Series 39 1-423.

Kumar G 1997 Geology of Arunachal Pradesh; Geological Society of India, Bangalore, 217p.

Kumar M, Mandal J, Dutta S K, Bhuyan D, Das B and Saikia B 2001 Palynostratigraphy of the subsurface sediments of Upper Assam basin, India; Geobios 34 $241-251$

Lokho K and Raju D S N 2007 Langhian (early Middle Miocene) foraminiferal assemblage from Bhuban Formation, Mizoram, NE India; J. Geol. Soc. India 70(3) 933-938.

Lokho K, Raju D S N and Azmi R J 2011 Paleoenvironmental and biostratigraphic significance of Uvigerinids and other foraminifera from the Bhuban Formation, AssamArakan Basin, Mizoram; J. Geol. Soc. India 77(3) 252260.

Lukose N G 1968 Microfossils from the middle Siwalik of Bihar, India; J. Palynology 4 107-112.

Mandaokar B D 1990 Palynology of Miocene rocks around Maibong, Assam; Geophytology 20 24-29.

Mandaokar B D 2000 Palynology and paleoenvironment of the Bhuban Formation (Early Miocene) of
Ramrikawn, near Aizawl, Mizoram; Palaeobotanist 49 317-324.

Mandaokar B D 2002 An interpretation of the palynology and palaeoecology of the Early Miocene Dulte Formation, Mizoram, India; Palaeobotanist 51 113-121.

Mandaokar B D 2015 Palynological assemblage from Early Miocene Bhuban Formation, Tripura (India): Age and palaeoenvironmental implication; Him. Geol. 36(1) 2332 .

Mandaokar B D and Mukherjee D 2014 Palynostratigraphy of the Cuddalore Formation (Early Miocene) of Panruti, Tamil Nadu, India; J. Palaeont. Soc. India 59(1) 6980.

Mathur Y K 1984 Cenozoic palynofossils, vegetation, ecology and climate of the north and North-western of SubHimalayan region; In: The evolution of the east Asian environment (ed.) Whyte R O, Centre of Asian Studies, Univ. Hong Kong, pp. 504-551.

Nandi B 1975 Palynostratigraphy of the Siwalik Group of Punjab; Him. Geol. 5 411-423.

Nandi B and Sharma R 1984 Palynology and biostratigraphy of the Boldamgiri Formation, Garo Hills, Meghalaya; In: Evolutionary botany and biostratigraphy (eds) Sharma A K, Mitra G C and Banerjee M, Proc. Symp. Current Trends in Life Sciences 10 565-580.

Rao M R 2004 Palynological investigation of the Sindhudurg Formation (Miocene) exposed at Kalviwadi, Sindhudurg District, Maharashtra, India; Palaeobotanist 53 123135.

Rao M R and Nair K K 1998 Palynological investigation of Miocene sediments exposed in Kannanellur-Kundara area, Quilon District, Kerala; Geophytology 27 49-59.

Rao M R and Verma P 2014 Palynological investigation of Neogene (Early Miocene) sediments of Mangalore basin, India: Palaeoenvironmental and palaeoclimatic implications; J. Geol. Soc. India 84(1) 55-67.

Sarkar S 1990 Siwalik pollen succession from Surai Khola of western Nepal and its reflection on palaeoecology; Palaeobotanist 38 319-324.

Sarkar S, Bhattacharyya A P and Singh H P 1994 Palynology of Middle Siwalik sediments (Late Miocene) from Bagh Rao, Uttar Pradesh; Palaeobotanist 42(2) 199-209.

Saxena R K 1991 A catalogue of fossil plants from IndiaPart 5 Cenozoic (Tertiary) A. Spores and pollen B. Fungi; Spec. Publ, Birbal Sahni Institute Palaeobotany Lucknow, $166 \mathrm{p}$.

Saxena R K and Rao M R 1996 Palynological investigation of the Boldamgiri Formation (Early Miocene) in the area, Garo Hills, Meghalaya; Geophytology 26 43-56.

Saxena R K, Rao M R and Singh H P 1987 Palynology of the Barail (Olicene) and Surma (Lower Miocene) sediments exposed along Sonapur-Badarpur Road Section, Jaintia Hills (Meghalaya) and Cachar (Assam) Part VI. Palynostratigraphic zonation; Palaeobotanist 35(2) 150-158.

Saxena R K and Tripathi S K M 2011 Indian fossil fungi; Palaeobotanist 60 1-208.

Saxena R K and Trivedi G K 2006 A catalogue of Tertiary spores and pollen from India; Diam. Jub. Spec. Publ., Birbal Sahni Institute Palaeobotany, Lucknow, 221p.

Singh B P, Singh Y R, Andotra D S, Patra A, Srivastava V K, Guruaribam V, Sijagurumayum U and Singh G P 2016a Tectonically driven Late Paleocene (57.9-54.7 Ma) 
transgression and climatically forced latest middle Eocene (41.3-38.0 Ma) regression on the Indian subcontinent; J. Asian Earth Sci. 115 124-132.

Singh H P and Sarkar S 1984 Palynological investigations of Ramshahr Well 1, Himachal Pradesh, India; Palaeobotanist 32 91-112.

Singh H P, Saxena R K and Rao M 1986 Palynology of the Barail (Oligocene) and Surma (Lower Miocene) sediments exposed along Sonapur-Badarpur road section, Jaintia Hills (Meghalaya) and Cachar (Assam) Part II. Fungal remains; Palaeobotanist 35(1) 93105.

Singh Y R, Li J, Singh B P and Guruaribam V 2013 Microforaminiferal linings from the upper part of the Upper Disang Formation at Gelmoul quarry, Churachandpur, Imphal valley and their bearing on palaeoenvironment; Curr. Sci. 105(9) 1223-1226.

Corresponding editor: Pratul K SARAswati
Singh Y R and Meera N 2013 Source rock palynology of Disang sediments of Imphal valley, Manipur; J. Earth Sci. Spec. 1 239-246.

Singh Y R, Sijagurumayum U and Guruaribam V 2011 Palaeoecology of the Upper Bhuban and Tipam sediments of Mizoram, India - palynological evidence; Him. Geol. 32 57-62.

Singh Y R, Singh B P and Li J 2015 Hydrocarbon potential of the Palaeogene Disang Group, Manipur region, India A Palynological approach; In: Petroleum geosciences: Indian contexts (ed.) Mukherjee S, Springer, Dordrecht, pp. 191-204.

Singh Y R, Singh B P, Murthy S, Kom K B, Singh K A and Guruaribam V 2016b Reworked Early Permian palynomorphs and Tertiary palynomorphs from the Upper Bhuban Formation (Miocene), Nagaland, India; Him. Geol. 37(1) 35-41. 